\title{
Effect of Water Flooding on Survival of Leptosphaeria biglobosa 'brassicae' in Stubble of Oilseed Rape (Brassica napus) in Central China
}

Xiang Cai, Jing Zhang, Mingde Wu, Daohong Jiang, Guoqing Li, and Long Yang, The State Key Lab of Agricultural Microbiology and the Key Laboratory of Phytopathology of Hubei Province, Huazhong Agricultural University, Wuhan 430070, China

\begin{abstract}
Cai, X., Zhang, J., Wu, M., Jiang, D., Li, G., and Yang, L. 2015. Effect of water flooding on survival of Leptosphaeria biglobosa 'brassicae' in stubble of oilseed rape (Brassica napus) in central China. Plant Dis. 99:1426-1433.

Blackleg (Phoma stem canker) caused by Leptosphaeria maculans and L. biglobosa is an economically important disease on oilseed rape and many cruciferous vegetables. Oilseed rape-rice rotation is a routine cultivation practice in central China. This study was conducted to assess the effect of flooding on survival of L. biglobosa 'brassicae' in the stubble of winter oilseed rape (Brassica napus). Basal stems with typical blackleg symptoms were collected and cut into small pieces $(2 \mathrm{~cm})$ that were either submerged in water at 16 and 20,20 and 28,28 and 33 , and 33 and $40^{\circ} \mathrm{C}$ (12 and $12 \mathrm{~h}$ ) or kept dry at room temperature (control). Moreover, in a field experiment, the stem pieces were placed on the soil surface in a rice field or in a cotton field and either flooded in water or not flooded, respectively. After 1,2, 4, 6, and 8 weeks, the stem pieces were sampled for retrieval of L. biglobosa 'brassicae' on V8-juice agar and for determination

of dry weight. Selected L. biglobosa 'brassicae' isolates from the stem pieces were identified by polymerase chain reaction (PCR). Results from the two experiments showed that, compared with the controls, flooding for 1 to 2 weeks substantially reduced recovery of L. biglobosa 'brassicae' and flooding for 4 weeks resulted in negligible recovery of $L$. biglobosa 'brassicae'. All of the 99 selected isolates produced a 444-bp DNA fragment in the PCR, confirming that they belong to L. biglobosa 'brassicae'. Results also indicated that flooding caused rapid decomposition of the stem pieces. After flooding for 8 weeks, the dry weight of the stem pieces was reduced by 28 to $42 \%$ in the laboratory experiment and by 26 to $36 \%$ in the field experiment. These results suggest that oilseed rape-rice rotation is probably an efficient way to reduce longevity of $L$. biglobosa 'brassicae' in stubble of winter oilseed rape in central China.
\end{abstract}

Blackleg (Phoma stem canker) caused by Leptosphaeria maculans and L. biglobosa (anamorph Phoma lingam) is an economically important disease on oilseed rape (Brassica napus and B. rapa) (Fitt et al. 2008; West et al. 2001) as well as on many cruciferous vegetables (Cai et al. 2014a,b; Dilmaghani et al. 2010). It is estimated that more than 1.6 billion US dollars per cropping season worldwide is lost to blackleg of oilseed rape (Barnes et al. 2010; Zhang et al. 2014). In China, the disease has become more and more prevalent in recent years and the incidence of blackleg reached $90 \%$ or higher in some areas (Cai et al. 2011; Li et al. 2013; Zhang et al. 2014).

L. maculans (formerly known as A type) and L. biglobosa (formerly known as B type) differ in how they infect oilseed rape (Fitt et al. 2006a). L. maculans infects the stem tissues of oilseed rape, causing stem canker. On the other hand, L. biglobosa tends to infect upper stems of oilseed rape, causing superficial lesions. In many countries such as Australia, Canada, France, Germany, Poland, and the United Kingdom, L. maculans and L. biglobosa coexist on Brassica hosts (Fitt et al. 2006b). For example, L. maculans and L. biglobosa coexist on oilseed rape in Canada and isolation frequency of the two pathogens is approximately 3 to 1 , respectively (Peluola et al. 2013). However, in some countries such as China, only L. biglobosa has been reported on Brassica hosts and also Raphanus sativus, whereas L. maculans has yet to be found (Cai et al. 2011, 2014a,b; Hao et al. 2014; Li et al. 2013; West et al. 2000). Molecular phylogenetic studies (Mendes-Pereira et al. 2003; Vincenot et al. 2008) indicated that L. maculans consists of at least two subgroups: L. maculans 'brassicae' on Brassica spp. and L. maculans 'lepidii' on Lepidium spp. There are at least six subgroups in L. biglobosa, including L. biglobosa 'australensis', L. biglobosa 'brassicae', L. biglobosa 'canadensis', L. biglobosa

Corresponding author: L. Yang; E-mail: yanglong@mail.hzau.edu.cn

Accepted for publication 23 March 2015.

http://dx.doi.org/10.1094/PDIS-10-14-1042-RE

(c) 2015 The American Phytopathological Society 'erysimii', L. biglobosa 'occiaustralensis', and L. biglobosa 'thlaspii'. L. biglobosa 'australensis' infects Brassica spp. in the United States and Australia, while L. biglobosa 'brassicae' infects various Brassica spp. in oilseed rape-growing areas except Canada and Australia. L. biglobosa 'canadensis', L. biglobosa 'erysimii', and L. biglobosa 'thlaspii' have been reported in Canada infecting Brassica spp., Erysimum spp., and Thlaspi arvense, respectively. L. biglobosa 'occiaustralensis' infects B. rapa in Australia.

Previous studies indicated that initial inoculum of blackleg of oilseed rape is from pathogen-infested seed or ascospores produced on the pathogen-colonized stubble of recently harvested plants (Fitt et al. 2006a; Hall 1992; Hall et al. 1996; Huang et al. 2007; West et al. 2001). Ascospores discharged from diseased stubble are usually airborne and dispersed onto cotyledons or leaves of oilseed rape, where they germinate under humid or wet conditions to produce hyphae that cause infection through stomata or wounds (West et al. 2001). The two fungi can also grow asymptomatically within tissues of the infected cotyledons or leaves through petioles to stems, where they cause stem canker (Hammond et al. 1985). Moreover, recent studies revealed that pycnidiospores (conidia) of L. maculans produced on stubble of oilseed rape also cause infection on leaves and stems of oilseed rape (Ghanbarnia et al. 2011; Li et al. 2006; Sprague et al. 2007; Travadon et al. 2007). Therefore, Leptosphaeria spp.-infected stubble plays an important role in the disease cycle of blackleg on oilseed rape. Management of diseased stubble by burning, incorporation into soil, and proper rotation of oilseed rape with noncruciferous crops is usually recommended to farmers to decrease the risk of blackleg epidemics on oilseed rape (Marcroft et al. 2004; West et al. 2001).

Many biotic and abiotic factors can affect survival of $L$. maculans and L. biglobosa in stubble of oilseed rape (Huang et al. 2007; Naseri et al. 2008; West et al. 2001). Naseri et al. (2008) reported that some saprophytic fungi such as Fusarium spp., Stachybotrys chartarum, and Trichoderma spp. can out-compete or replace L. maculans in diseased stubble of oilseed rape buried in soil.

Dry and low-temperature conditions favor the survival of $L$. maculans and L. biglobosa (Sosnowski et al. 2006). In contrast, wet and high-temperature conditions that favor stubble decomposition and 
reduce the longevity of $L$. maculans and L. biglobosa. Peluola et al. (2013) assessed the effect of flooding on survival of L. maculans and L. biglobosa in oilseed rape stubble and reported that flooding for 2 weeks substantially reduced pathogen recovery compared with the nonflooded control. After flooding for 6 weeks, neither $L$. maculans nor L. biglobosa was recovered regardless of temperature (12 to $40^{\circ} \mathrm{C}$ ). This study strongly suggests that flooding is an effective measure for controlling L. maculans and L. biglobosa. However, field experiments are still needed to warrant the validity of the laboratory study.

Winter rape is largely cultivated along the Yangtze River in China, where there are four distinctive seasons per year, and the average temperatures of the spring and summer ranges from 20 to $33^{\circ} \mathrm{C}$, although the high temperature in summer can reach $40^{\circ} \mathrm{C}$ (World Meteorological Organization 2014). After harvest of the winter oilseed rape, the fields are usually planted with summer crops such as cotton (Gossypium hirsutum), maize (Zea mays), and paddy rice (Oryza sativa). As a consequence, the stubble of oilseed rape is either submerged under water (flooded) in rice fields or exposed to fluctuating dry and wet conditions in fields of cotton or maize. Data on the survival of indigenous L. biglobosa in stubble of oilseed rape under crop cultivation systems in China is not available. Therefore, laboratory and field studies were conducted to assess the survival of L. biglobosa in oilseed rape stubble that was flooded for various periods of time.

\section{Materials and Methods}

Collection and processing of diseased stubble of oilseed rape. Diseased stubble of oilseed rape (B. napus 'Zhongyou No. 8') with the typical blackleg symptoms on stems (Fitt et al. 2006a) was collected on 15 May 2013 and 20 May 2014 from a field in the Oil Crops Research Institute of the Chinese Academy of Agricultural Sciences (CAAS-OCRI, Wuhan, China). Morphology of pycnidia and pycnidiospores (conidia) formed on the surface of the diseased stems was observed under a compound light microscope. Only diseased stems with pycnidia and pycnidiospores morphologically similar or identical to those formed by $P$. lingam were selected for this study (Chen et al. 2010). The stem pieces were air dried at room temperature (20 to $25^{\circ} \mathrm{C}$ ) for 1 month and transversely cut into small pieces (approximately $2 \mathrm{~cm}$ long) using a pair of gardening scissors. Only stem pieces with the disease surface area accounting for $>75 \%$ of the total area were selected for this study.

Laboratory experiment. The diseased stubble of oilseed rape collected in 2013 was used for the laboratory experiment. Two air-dried stem pieces of oilseed rape were wrapped in a nylon pouch with mesh size of $2.2 \mathrm{~mm}^{2}$ and the pouch was tied shut with a red-colored plastic string for easy sampling identification during the flooding treatment. In total, 100 nylon pouches containing 200 air-dried stem pieces were prepared. Twenty pouches were kept dry at room temperature (25 to $35^{\circ} \mathrm{C}$ ) as the nonflooding control treatment. The remaining 80 nylon pouches were placed in 100-ml glass jars, each containing $20 \mathrm{~cm}^{3}$ of yellow-brown clay soil, which was taken from a field near the campus of Huazhong Agricultural University, Wuhan, China. The field had been planted for oilseed rape for many years. The soil, with a $\mathrm{pH}$ value of 6.0 , carbon content of $1.1 \%$ (wt/wt), and nitrogen content of $0.1 \%(\mathrm{wt} / \mathrm{wt})$, is widely distributed in central China (Yang et al. 2010). There were five pouches per jar. The jars were flooded with tap water, $50 \mathrm{ml}$ per jar, and each covered loosely with plastic caps. They were divided into four groups with four jars per group. Finally, the four groups of glass jars were placed in four incubators with temperature regimes of 16 and 20, 20 and 28, 28 and 33, and 33 and $40^{\circ} \mathrm{C}(12 \mathrm{~h}$ of low temperature in darkness and $12 \mathrm{~h}$ of high temperature in light), respectively. The light intensity in the incubators was approximately $200 \mu \mathrm{E} \cdot \mathrm{m}^{-2} \cdot \mathrm{s}^{-1}$. The experiment was repeated once.

To estimate decomposition of the stem pieces during flooding, the weight of stem pieces was measured before and after flooding. The selected stem pieces were dried in an oven $\left(60^{\circ} \mathrm{C}\right)$ for 3 days. Two heat-dried stem pieces were each weighed (original weight $\left[\mathrm{W}_{\mathrm{O}}\right]$ ) and wrapped in a nylon pouch, which was subsequently tied with a green-colored plastic string. In total, 80 nylon pouches containing 160 heat-dried stem pieces were prepared. Five nylon pouches were placed in a soil-containing glass jar and flooded with tap water, as mentioned above. The jars were divided into four groups, four jars per group. The four groups of jars were placed in the four incubators with temperature regimes of 16 and 20, 20 and 28, 28 and 33, and 33 and $40^{\circ} \mathrm{C}(12 \mathrm{~h}$ of low temperature in darkness and $12 \mathrm{~h}$ of high temperature in light), respectively. The experiment was also repeated once.

Assessment of $\boldsymbol{L}$. biglobosa survival. At week 1, 2, 4, 6, or 8 after flooding, a nylon pouch was sampled from a glass jar and, in total, four pouches were obtained for a temperature treatment. The eight stem pieces were rinsed in distilled water to remove soil particles and used to assess survival of L. biglobosa. Eight stem pieces were also sampled from the control treatment at each flooding date. The stem pieces from each treatment were cut both transversely and longitudinally into 100 stem sections (approximately $2 \mathrm{~mm}$ in length by $5 \mathrm{~mm}$ in width). The sections were surface sterilized by dipping in $75 \%$ ethanol ( $\mathrm{vol} / \mathrm{vol}$ ) for $60 \mathrm{~s}$ followed by $5 \% \mathrm{NaOCl}$ for $60 \mathrm{~s}$, then rinsed three times in sterilized water amended with lactic acid $(0.85 \%, \mathrm{vol} / \mathrm{vol})$. After sterilization, the stem sections were blotted dry with sterilized paper towels and placed for $1 \mathrm{~h}$ in a laminar flow hood, before they were individually transferred onto V8-juice agar (V8A) (200 $\mathrm{ml}$ of $\mathrm{V} 8$ juice, 0.75 of $\mathrm{g} \mathrm{CaCO}_{3}, 12 \mathrm{~g}$ of agar, and $1,000 \mathrm{ml}$ of water) in petri dishes ( $9 \mathrm{~cm}$ in diameter), 25 stem sections per dish. To inhibit bacterial contamination, V8A was amended with streptomycin sulfate (North China Pharmaceutical Company Ltd.) at $100 \mu \mathrm{g} / \mathrm{ml}$ and 1\% (vol/vol) Triton X-100 (Biosharp; Hefei). The dishes were placed in an incubator at $22^{\circ} \mathrm{C}$ for 10 days under fluorescent light with a 12-h photoperiod. The resulting colonies of L. biglobosa that developed from the stem sections were identified based on the colony color, morphology of mycelia, and pycnidia and pycnidiospores that formed on the colony surface (Chen et al. 2010). To confirm identification, putative colonies of L. biglobosa were purified by transferring a mycelial agar plug from each colony to a V8A dish. The cultures were incubated at $25^{\circ} \mathrm{C}$ for 14 days for further PCR identification using species-specific primers reported in previous studies (Cai et al. 2014 a,b; Liu et al. 2006). The incidence of L. biglobosa recovery (\%) was calculated based on the number of the stem sections on which colonies of L. biglobosa developed of the 25 stem sections in a petri dish.

Assessment of stubble decomposition. To assess the impact of flooding on decomposition of stubble of oilseed rape under each temperature, four preweighed and labeled nylon pouches with eight stem pieces were sampled from four glass jars in an incubator (one pouch from a jar) at week 1, 2, 4, 6, or 8 after flooding. The pouches were rinsed in tap water to remove soil particles. The stem pieces from each nylon pouch were removed, placed in an oven at $60^{\circ} \mathrm{C}$ for 3 days, and individually weighed (weight after flooding $\left[\mathrm{W}_{\mathrm{F}}\right]$ ). Decomposition of the stubble after flooding was evaluated as the percentage of reduction in the stubble dry weight $(\mathrm{R})$, which was calculated using the following formula: $\mathrm{R}=\left(\mathrm{W}_{\mathrm{O}}-\mathrm{W}_{\mathrm{F}}\right) / \mathrm{W}_{\mathrm{O}} \times 100 \%$.

Field experiment. Two field experiments were conducted in 2013 and 2014, respectively, to compare survival of L. biglobosa in stubble of oilseed rape in a rice field that was flooded according to local production practices with infested stubble placed on the soil surface in a cotton field. The experiments were done in two neighboring fields located at the campus of Huazhong Agricultural University based in Wuhan, China (E114 $\left.21^{\prime}, \mathrm{N} 30^{\circ} 37^{\prime}\right)$, on a field with lateplanted rice (O. sativa 'Hesheng Wan You No. 1') and another field which was planted to cotton (G. hirsutum 'Huaza Mian H318'). In May of each year, stubble of oilseed rape (B. napus Zhongyou No. 8 ) with typical blackleg symptoms was collected, cut into stem pieces ( $2 \mathrm{~cm}$ long), and air dried or oven dried as described above. Similar to the laboratory experiment, the stem pieces were wrapped in nylon pouches, two stem pieces per pouch, and the pouches were individually tied with either red strings (for assessing survival of L. biglobosa) or green strings (for assessing stubble decomposition).

There were two treatments in each experiment: the rice-field treatment and cotton-field treatment. For the rice-field treatment, 20 nylon 
pouches tied with red strings and 20 nylon pouches tied with green strings were placed into a big net bag and submerged under water in the rice field. For the cotton-field treatment, 20 nylon pouches tied with red strings and 20 nylon pouches tied with green strings were placed in a plastic mesh tray (14 by 7 by $4 \mathrm{~cm}$, length by width by height) that was covered with a piece of nylon window screen and placed on the soil surface in the cotton field. The 2013 experiment was started on 12 July as trial 1 and repeated on 13 July as trial 2. The 2014 experiment was started on 7 July as trial 3 and repeated on 8 July as trial 4 . The isolation and stubble decomposition assessment were done using the procedures described above. Daily air temperature and rainfall data for the periods of the field trials were kindly provided by the Wuhan Weather Bureau.

PCR identification of $\boldsymbol{L}$. biglobosa. Multiplex PCR identification was conducted to confirm morphological identification of L. biglobosa isolates obtained from the laboratory and field experiments in this study. The PCR primers LbigF, LmacF, and LmacR produce two DNA fragments specific for discrimination of L. maculans 'brassicae' (331-bp DNA fragment) and L. biglobosa 'brassicae' (444-bp DNA fragment) (Liu et al. 2006). Meanwhile, isolate UK-1 of L. maculans (Balesdent et al. 2005) and isolate W10 of L. biglobosa (Cai et al. 2011) from B. napus were used as references in the PCR identification. Genomic DNA (gDNA) was extracted from the mycelium of each selected isolate of L. biglobosa in this study and isolate W10 using the cetyltrimethylammonium bromide method (Möller et al. 1992). The gDNA of strain UK-1 was kindly provided by Drs. Y. J. Huang and B. D. L. Fitt of University of Hertfordshire (Hatfield, Hertfordshire, UK). The 25- $\mu$ l PCR reaction volume contained $2.5 \mu \mathrm{l}$ of $10 \times$ PCR buffer, $0.5 \mu \mathrm{l}$ of dNTPs $(2.5 \mathrm{mM}), 0.25 \mu \mathrm{l}$ of rTaq DNA polymerase $(1.25 \mathrm{U}$; TaKaRa), $3 \times 0.5 \mu l$ of primers $(20 \mu \mathrm{M}), 1 \mu \mathrm{l}$ of gDNA $(50 \mathrm{ng} / \mu \mathrm{l})$, and $19.25 \mu \mathrm{l}$ of doubledistilled $\mathrm{H}_{2} \mathrm{O}$. The PCR was performed in a $\mathrm{S} 1000$ Thermal Cycler (Bio-Rad) with the following program: one cycle at $95^{\circ} \mathrm{C}$ for $5 \mathrm{~min}$; followed by 35 cycles of $95^{\circ} \mathrm{C}$ for $1 \mathrm{~min}, 68^{\circ} \mathrm{C}$ for $30 \mathrm{~s}$, and $72{ }^{\circ} \mathrm{C}$ for $45 \mathrm{~s}$; and, finally, $72^{\circ} \mathrm{C}$ for $10 \mathrm{~min}$. The resulting PCR mixture was loaded in an agarose gel $(1 \%, \mathrm{wt} / \mathrm{vol})$ for electrophoresis and, after electrophoresis, the gel was stained with ethidium bromide solution $(1.5 \mu \mathrm{g} / \mathrm{ml})$ and visualized on an UV transilluminator.

Data analysis. Effects of flooding on percent recovery of L. biglobosa (arcsine-transformed) were determined using analysis of variance (ANOVA) in SAS software (version 8.1; SAS Institute). Because the parameters percent recovery of L. biglobosa and dry weight reduction of stem pieces from each repeat of the laboratory experiment were homogenous according to the Bartlett test $(P<$ $0.001)$, the data were pooled and individually arcsine transformed for ANOVA. Effects of temperature, duration of flooding, and temperature-duration of flooding interaction on the frequency of pathogen recovery and dry weight reduction of stem pieces in each experiment were separately determined using the GLM procedure in ANOVA. Mean percent recovery of L. biglobosa for each treatment in both the laboratory and field trials was compared at $P<$ 0.05 according to Duncan's multiple range test and Student's $t$ test, respectively.

Linear regression analysis was used to evaluate the correlation between the recovery percentage of L. biglobosa (arcsine-transformed, $Y$ ) and the reduction percentage of stem piece dry weight (arcsinetransformed, $X$ ) using the GLM procedure in the SAS software. The significance of the correlation coefficient value $(r)$ between the two parameters in each experiment were determined by Student's $t$ test at $P=0.05$ level.

\section{Results}

Laboratory experiment. Flooding reduced survival of L. biglobosa in stem pieces of oilseed rape (Fig. 1A). When the stem pieces were kept dry at room temperature $\left(25\right.$ to $\left.35^{\circ} \mathrm{C}\right)$ for $1,2,4,6$, and 8 weeks, percent recovery of $L$. biglobosa was 74, 69, 53, 49 and $40 \%$, respectively. However, when the stem pieces were flooded in water at various temperatures for 1 to 8 weeks, percent recovery of L. biglobosa was significantly influenced by temperature and flooding duration $(P=0.0016$ and $P<0.001$, respectively). A significant interaction between temperature and flooding duration $(P<0.001)$ was detected (Table 1). After flooding for 1 week, the percent recovery of L. biglobosa was $31 \%$ at 16 and $20^{\circ} \mathrm{C}$ and $2 \%$ at 33 and $40^{\circ} \mathrm{C}$. After flooding for 2 weeks, the L. biglobosa-recovery percentage was $6 \%$ at 16 and $20^{\circ} \mathrm{C}$ and $0.5 \%$ at 33 and $40^{\circ} \mathrm{C}$. After flooding for 4 to 8 weeks, L. biglobosa was not recovered from all temperature treatments.

Flooding for 1 to 8 weeks at 16 and 20, 20 and 28, 28 and 33, and 33 and $40^{\circ} \mathrm{C}$ affected stubble decomposition, as indicated by reduction in the dry weight of the stem pieces (Fig. 1B). Both temperature and flooding duration significantly $(P<0.001)$ affected stubble decomposition (Table 1), and there was no interaction between temperature and flooding duration $(P=0.1344)$. After flooding for 1 week, the dry weight of the stem pieces were reduced by $15 \%$ at 16 and 20 , 20 and 28 , and 28 and $33^{\circ} \mathrm{C}$, and $21 \%$ at 33 and $40^{\circ} \mathrm{C}$. After flooding

Table 1. Summary of statistical analysis: effect of flooding temperature and duration on survival of Leptosphaeria biglobosa in oilseed rape stubble and stubble decomposition in the laboratory experiment

\begin{tabular}{|c|c|c|c|c|c|c|}
\hline \multirow[b]{2}{*}{ Factor } & \multicolumn{3}{|c|}{ Recovery of $L$. biglobosa } & \multicolumn{3}{|c|}{$\begin{array}{l}\text { Reduction in weight } \\
\text { of stem pieces }\end{array}$} \\
\hline & $\mathbf{D F}^{\mathrm{a}}$ & $F$ value & $P$ value & DF & $F$ value & $P$ value \\
\hline Temperature $(\mathrm{T})$ & 3 & 5.3526 & 0.0016 & 3 & 11.8044 & $<0.001$ \\
\hline Duration (D) & 4 & 18.5697 & $<0.001$ & 4 & 42.0105 & $<0.001$ \\
\hline $\mathrm{T} \times \mathrm{D}$ & 12 & 3.5534 & $<0.001$ & 12 & 1.4905 & 0.1344 \\
\hline
\end{tabular}

${ }^{\mathrm{a}} \mathrm{DF}=$ degree of freedom.
A

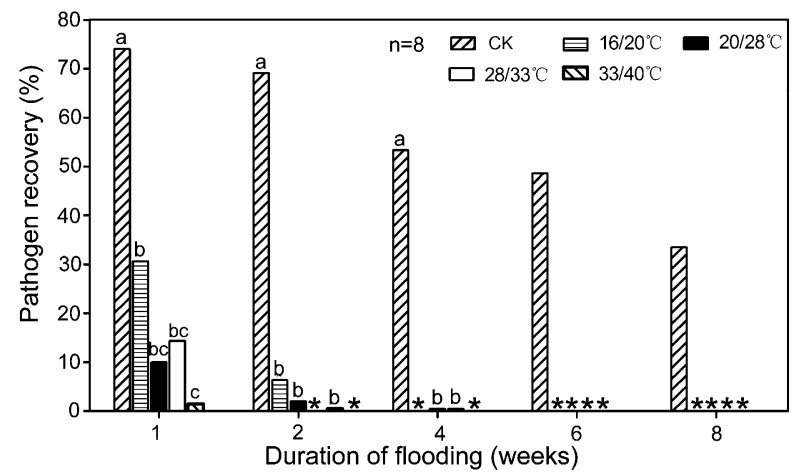

B

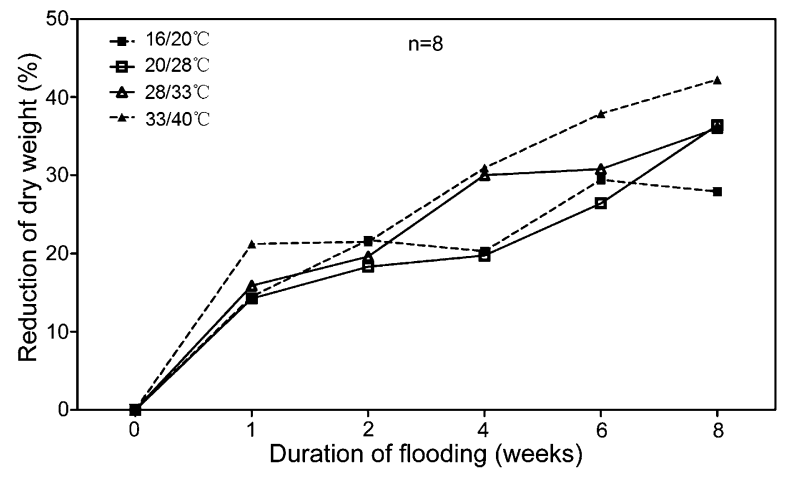

Fig. 1. A, Recovery of Leptosphaeria biglobosa in stubble of winter oilseed rape and $\mathbf{B}$, reduction in dry weight of stubble under flooded conditions at different temperatures (laboratory experiment). Treatment means labeled with the same letters are not significantly different $(P>0.05)$ according to Duncan's multiple range test. CK $=$ stubble stored under dry conditions at room temperature; the symbol * indicates no detectable. 
for 8 weeks, the dry weight of the stem pieces were reduced by $28 \%$ at 16 and $20^{\circ} \mathrm{C}$, by $36 \%$ at 20 and 28 and 28 and $33^{\circ} \mathrm{C}$, and by $42 \%$ at 33 and $40^{\circ} \mathrm{C}$. Regression analysis showed that the recovery percentage of $L$. biglobosa in stem pieces $(Y)$ was inversely proportional to the reduction percentage of the stem piece dry weight $(X): Y=$ $43.422-1.2128 X(r=-0.7024, P<0.01)$.
Field experiment. Trials 1 and 2 were initiated on 12 and 13 July 2013, respectively, and ended on 5 and 6 September 2013, respectively. During that period, air temperatures ranged from 15 to $42^{\circ} \mathrm{C}$ $\left(30^{\circ} \mathrm{C}\right.$ on average) and cumulative rainfall was $163 \mathrm{~mm}$ (Fig. 2A). Trials 3 and 4 were initiated on 7 and 8 July 2014, respectively, and ended on 31 August and 1 September 2014, respectively. During

A

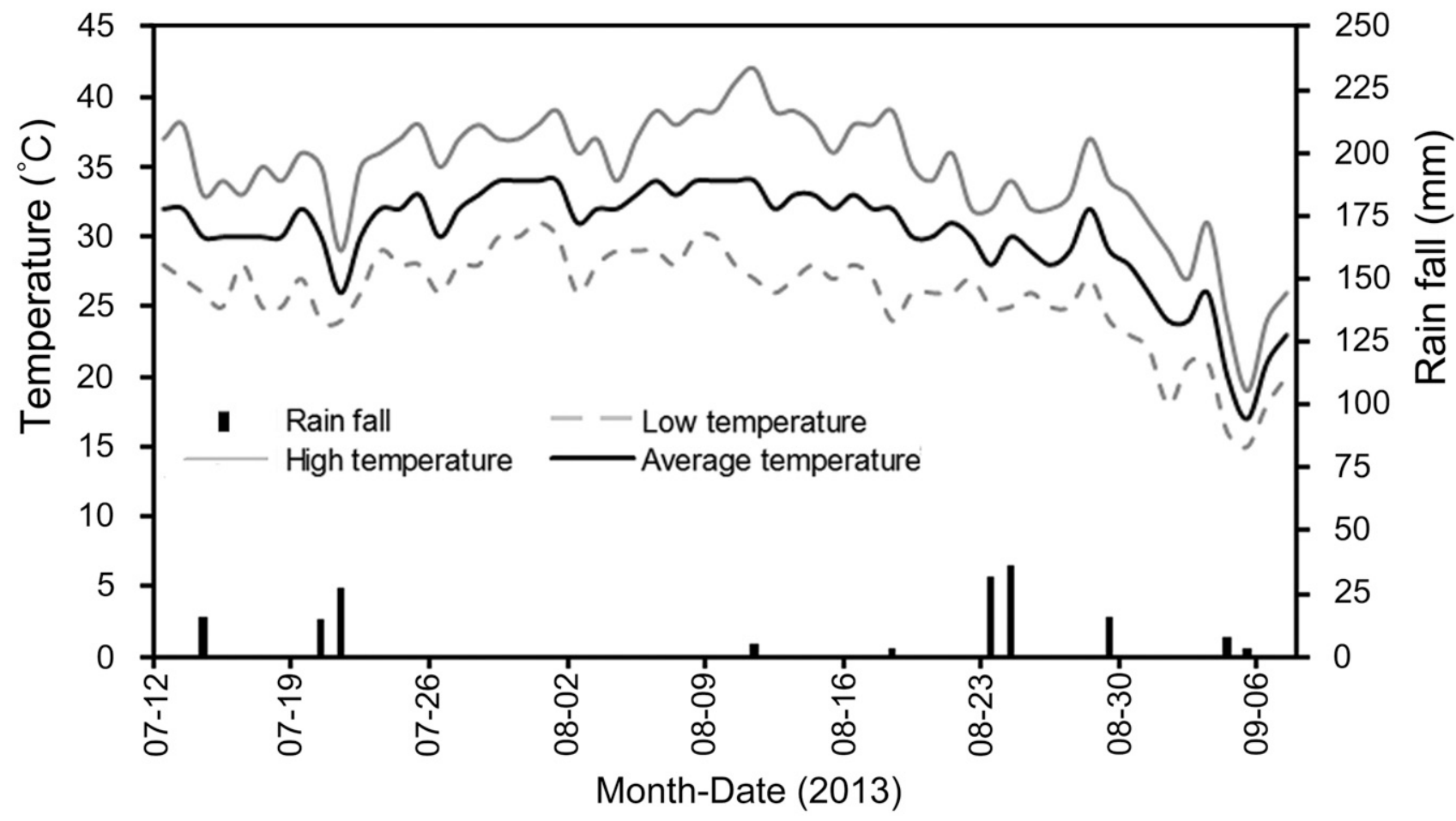

B

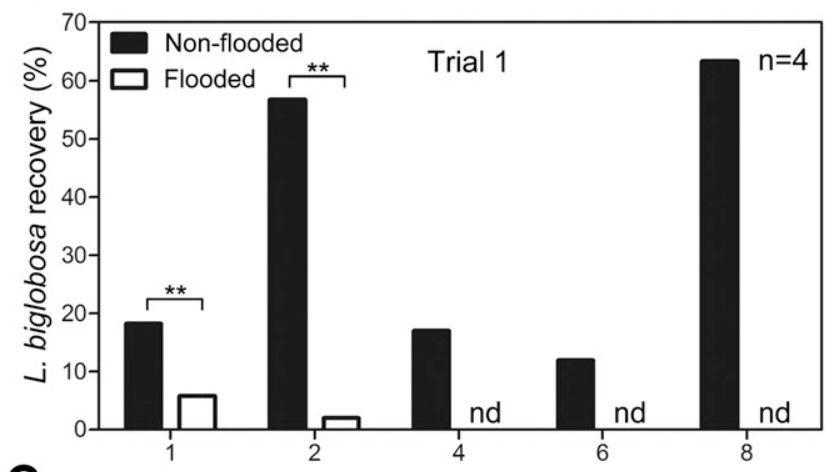

C

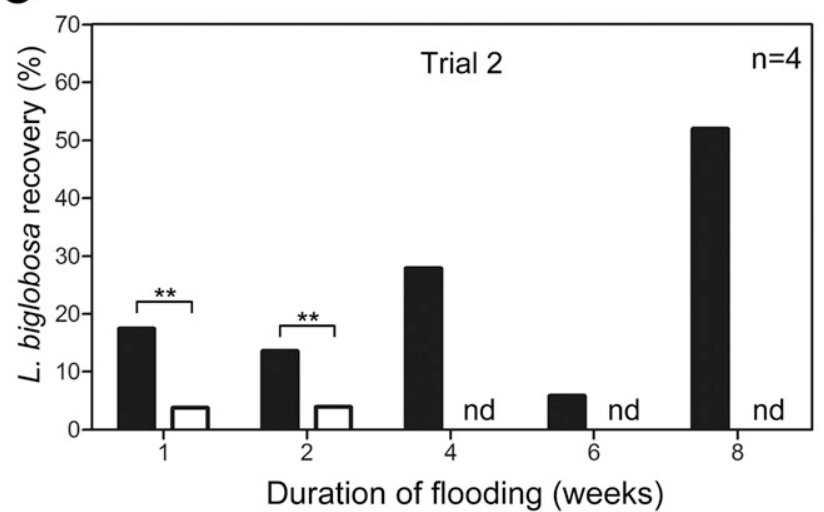

D

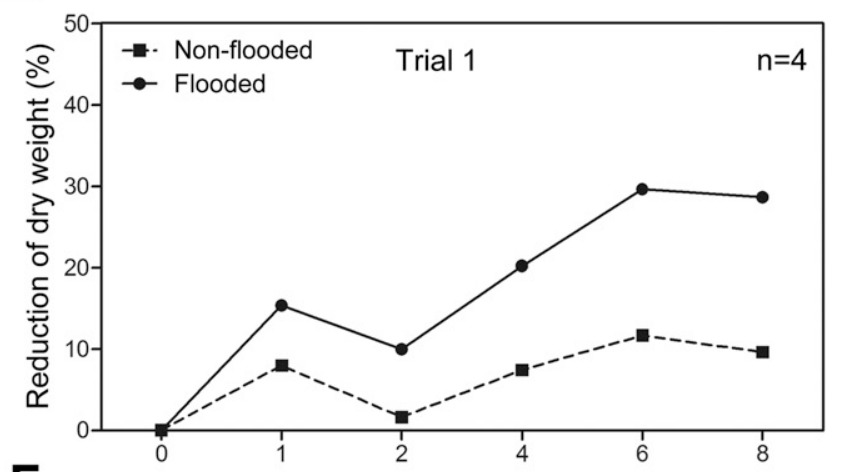

E

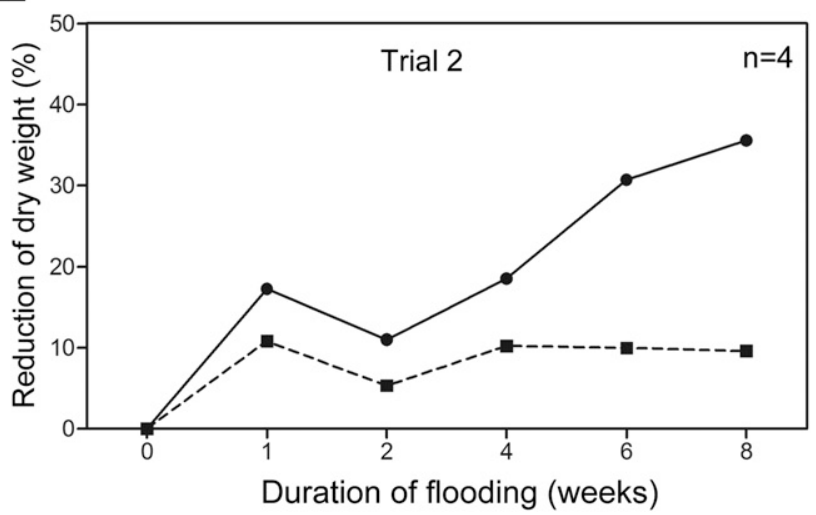

Fig. 2. A, Temperature and rainfall for the 2013 field experiment; $\mathbf{B}$ and $\mathbf{C}$, recovery of Leptosphaeria biglobosa in trials 1 and 2; and $\mathbf{D}$ and $\mathbf{E}$, reduction in dry weight of stem pieces in the two trials. In each histogram, the symbol ${ }^{* *}$ indicates a significant difference $(P<0.01)$ in percentage of recovery of $L$. biglobosa between the rice-field treatment (flooded) and the cotton-field treatment (nonflooded) according to Student's $t$ test; nd $=$ not detectable. 
that period, the air temperatures ranged from 20 to $37^{\circ} \mathrm{C}\left(27^{\circ} \mathrm{C}\right.$ on average) and the cumulative rainfall was $199 \mathrm{~mm}$ (Fig. 3A).

L. biglobosa was consistently retrieved from the stem pieces placed in the cotton field for 1 to 8 weeks in the four trials (Figs. $2 \mathrm{~B}$ and $\mathrm{C}$ and $3 \mathrm{~B}$ and $\mathrm{C}$ ). Percent recovery of L. biglobosa was 12 to $63 \%$ in trial 1,6 to $52 \%$ in trial 2,12 to $27 \%$ in trial 3 , and 5 to $14 \%$ in trial 4 . The length of time the stem pieces were left in the cotton field influenced percent recovery of L. biglobosa in 2013 $(P=0.0027)$ but not in $2014(P=0.8715)$ (Table 2$)$. In contrast, L. biglobosa was recovered from the stem pieces that were flooded in the rice field only in weeks 1 and 2 of trials 1,2, and 3 and week 1 of trial 4 , with the recovery percentages being less than $6 \%$ in these trials (Figs. $2 \mathrm{~B}$ and $\mathrm{C}$ and $3 \mathrm{~B}$ and $\mathrm{C}$ ). Flooding duration significantly affected percentage of $L$. biglobosa recovery $(P<0.001$ in trials

A

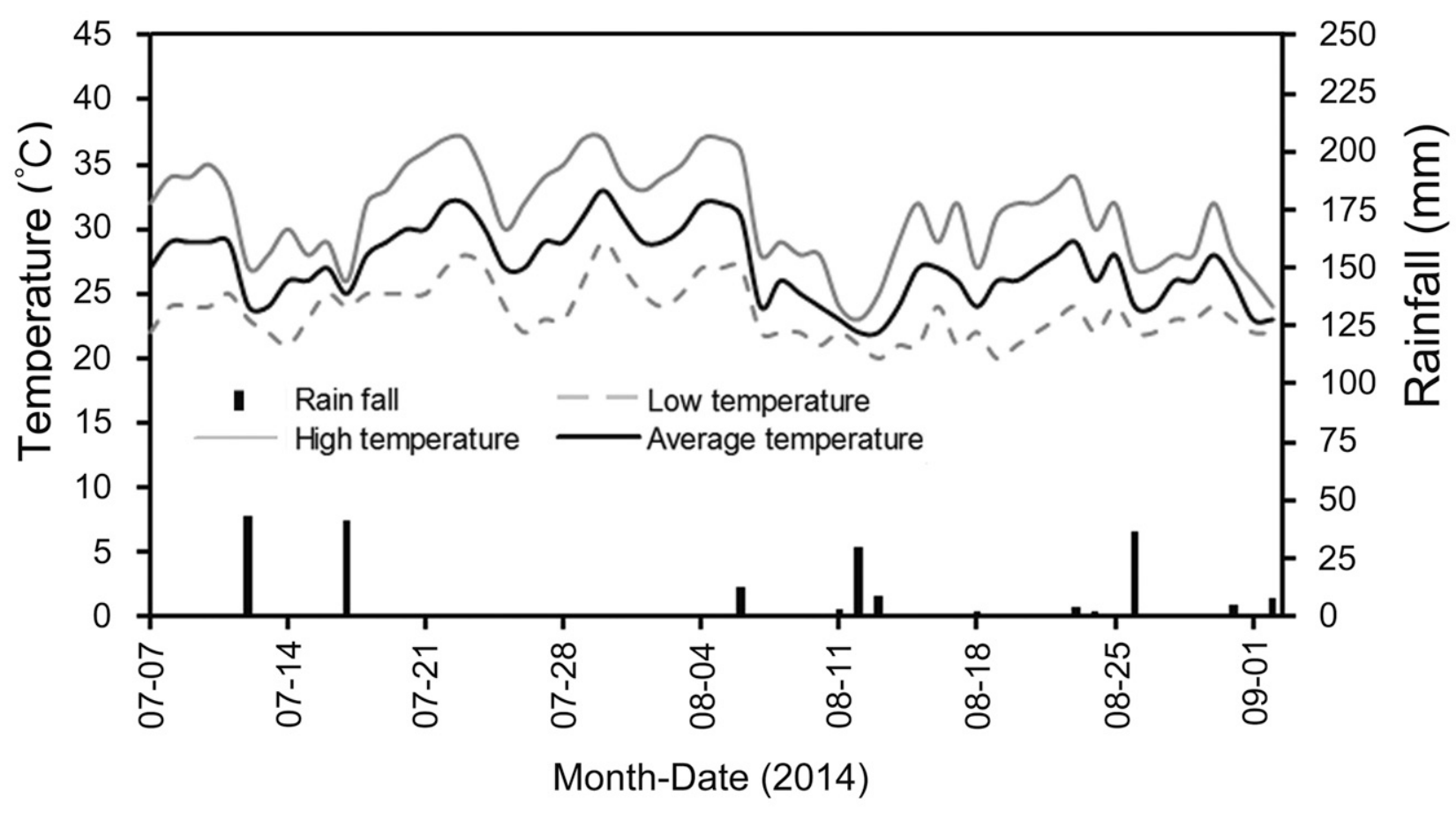

B

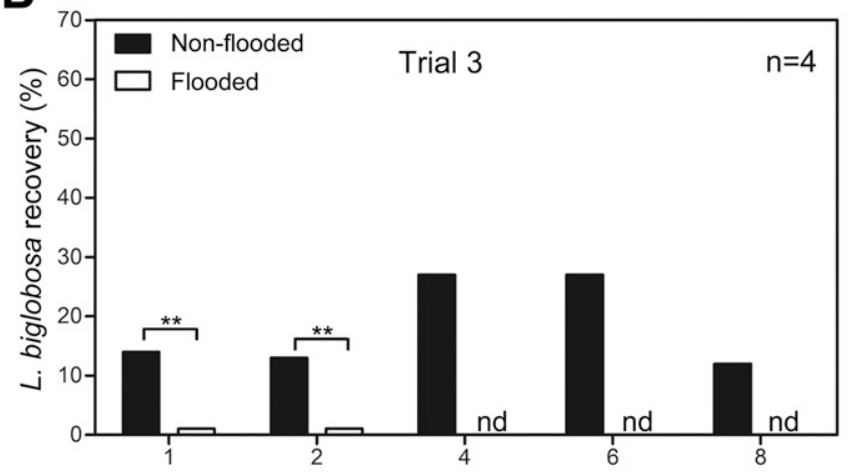

C

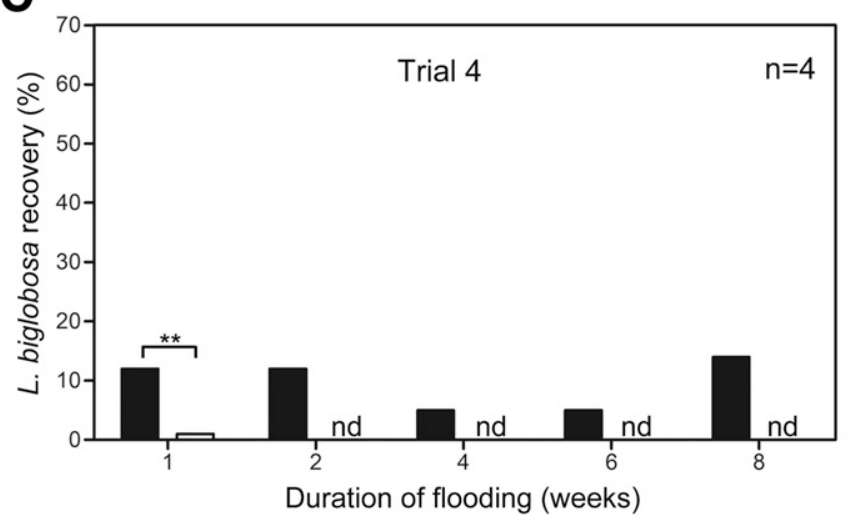

D

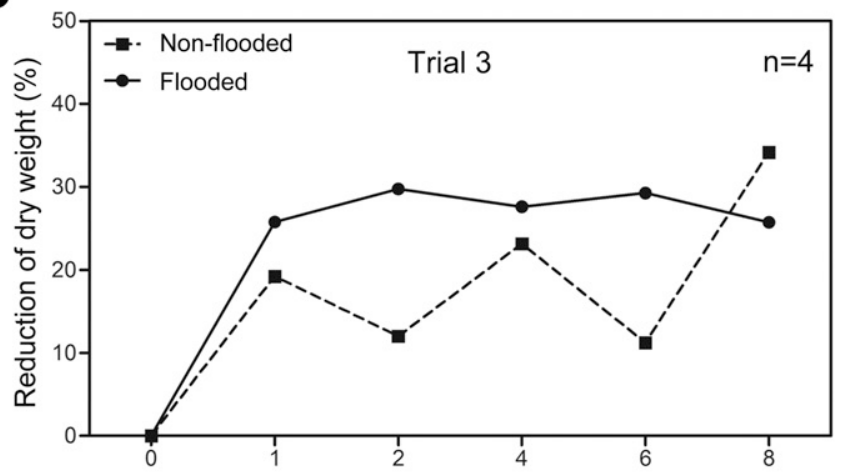

E

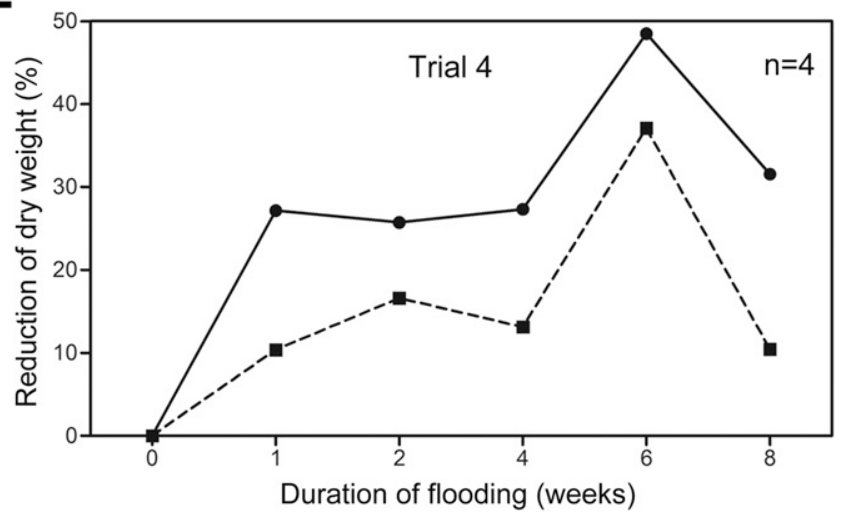

Fig. 3. A, Temperature and rainfall for the 2014 field experiment; $\mathbf{B}$ and $\mathbf{C}$, recovery of Leptosphaeria biglobosa in trials 3 and 4 ; and $\mathbf{D}$ and $\mathbf{E}$, reduction in dry weight of stem pieces in the two trials. In each histogram, the symbol ${ }^{* *}$ indicates a significant difference $(P<0.01)$ in percentage of recovery of $L$. biglobosa between the rice-field treatment (flooded) and the cotton-field treatment (nonflooded) according to Student's $t$ test; nd $=$ not detectable. 
1 and 2 and $P=0.0215$ in trials 3 and 4) (Table 2). After flooding for 4 to 8 weeks in trials 1,2 , and 3 and 2 to 8 weeks in trial 4 , no viable L. biglobosa was recovered from the stem pieces.

Reduction in dry weight of the stem pieces was observed in all four field trials (Figs. 2D and E and 3D and E). At each sampling time, the percentage of the stem weight reduction in the rice field, in most cases, was greater than that in the cotton field. In the rice field, duration significantly affected percentage of dry weight reduction of stem pieces in both $2013(P<0.001)$ and $2014(P=0.0486)$ (Table 2$)$. In the cotton field, duration significantly affected percentage of dry weight reduction of stem pieces in $2013(P=0.0016)$ but not in $2014(P=0.7312)$. After 8 weeks, the percentages of weight reduction of the stem pieces in trials $1,2,3$, and 4 were $29,36,26$, and $32 \%$, respectively, in the rice field, compared with $10,10,34$, and $10 \%$, respectively, in the cotton field.

Similar to the laboratory experiment, a negative correlation relationship between survival of L. biglobosa $(Y)$ and decomposition of stem pieces of oilseed rape $(X)$ was observed in the field experiment. The equations for the rice field and the cotton field are $Y=19.092-0.5301 X(r=-0.666, P<0.01)$ and $Y=41.116-$ $0.7166 X(r=-0.4415, P<0.05)$, respectively.

PCR identification of $\boldsymbol{L}$. biglobosa. In total, 1,144 isolates of L. biglobosa were recovered from the stem pieces of oilseed rape. On V8A, all the isolates produced yellowish or reddish brown pigments and formed black globose pycnidia with pink conidial ooze after incubation at $25^{\circ} \mathrm{C}$ for 10 days (data not shown). Ninety-nine isolates (Table 3) were selected for PCR identification, and L. maculans UK-1 (Balesdent et al. 2005) and L. biglobosa 'brassicae' W10 (Cai et al. 2011) were used as reference strains. PCR produced a 331-bp DNA fragment for L. maculans UK-1 (Fig. 4) and a 444-bp DNA fragment for L. biglobosa $\mathrm{W} 10$ and the 99 isolates obtained from this study (Fig. 4; Table 3), indicating that all the isolates recovered from the stem pieces collected from the field at CAAS-OCRI belonged to L. biglobosa 'brassicae'.

\section{Discussion}

Both the laboratory and field experiments in this study demonstrated that flooding substantially reduced the survival of L. biglobosa in winter oilseed rape stubble collected from a field in Wuhan, central China (Figs. 1, 2, and 3). Our data confirm results reported by Peluola et al. (2013) in Canada and suggest that flooding might be an effective measure for controlling blackleg of oilseed rape caused by L. maculans and L. biglobosa. In central China, flooding can be conveniently achieved by oilseed rape-rice rotation, which may not only suppress blackleg but also suppress other diseases such as Sclerotinia stem rot caused by Sclerotinia sclerotiorum, because flooding can destroy sclerotia of S. sclerotiorum (Moore 1949).

Previous studies reported that only L. biglobosa infects oilseed rape, radish ( $R$. sativus), and purple cai-tai (B. campestris subsp. chinensis var. purpurea) ( Cai et al. 2011, 2014 a,b; Hao et al. 2014; Li et al. 2013; West et al. 2000) in China. Cai et al. (2011, 2014 a,b) reported that L. biglobosa on these crops belongs to L. biglobosa 'brassicae' based on analysis of the internal transcribed spacer

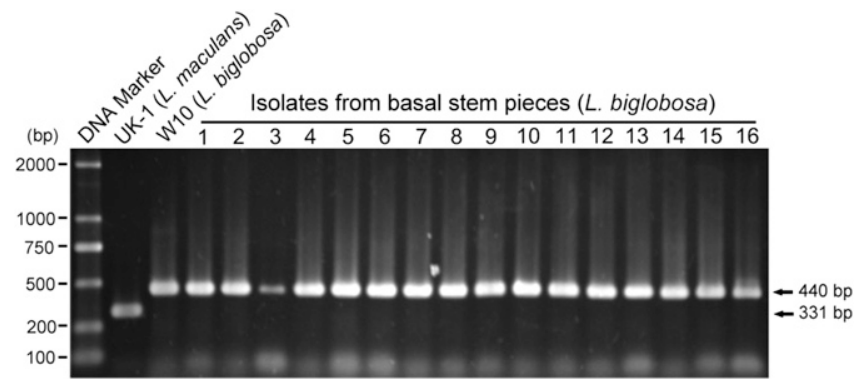

Fig. 4. Polymerase chain reaction identification of the selected isolates of Leptosphaeria biglobosa from stem pieces of oilseed rape.

Table 2. Summary of statistical analysis: effect of duration on survival of Leptosphaeria biglobosa in stubble of oilseed rape and stubble decomposition in the field experiments

\begin{tabular}{|c|c|c|c|c|c|c|}
\hline \multirow[b]{2}{*}{ Treatment } & \multicolumn{3}{|c|}{ Recovery of L. biglobosa } & \multicolumn{3}{|c|}{ Reduction in dry weight of stem pieces } \\
\hline & DF $^{\mathbf{a}}$ & $F$ value & $P$ value & DF & $F$ value & $P$ value \\
\hline \multicolumn{7}{|c|}{ Stem pieces in the rice field } \\
\hline Trials 1 and 2 (2013) & 4 & 5.8799 & $<0.001$ & 4 & 9.1468 & $<0.001$ \\
\hline Trials 3 and 4 (2014) & 4 & 3.2965 & 0.0215 & 4 & 2.6637 & 0.0486 \\
\hline \multicolumn{7}{|c|}{ Stem pieces in the cotton field } \\
\hline Trials 1 and 2 (2013) & 4 & 5.0147 & 0.0027 & 4 & 5.4850 & 0.0016 \\
\hline Trials 3 and 4 (2014) & 4 & 0.3067 & 0.8715 & 4 & 0.5065 & 0.7312 \\
\hline
\end{tabular}

${ }^{\mathrm{a}} \mathrm{DF}=$ degree of freedom.

Table 3. Identification of selected isolates of Leptosphaeria biglobosa from basal stems of Brassica napus

\begin{tabular}{|c|c|c|c|c|c|}
\hline \multirow[b]{2}{*}{ Origin } & \multirow[b]{2}{*}{ Number of isolates } & \multirow[b]{2}{*}{ Brown pigments ${ }^{\mathrm{c}}$} & \multirow[b]{2}{*}{ Pycnidia and pink spore oozes ${ }^{c}$} & \multicolumn{2}{|c|}{ PCR markers ${ }^{b}$} \\
\hline & & & & 331 bp & 444 bp \\
\hline \multicolumn{6}{|l|}{ Stem pieces } \\
\hline Flooded (indoor experiment, 2013) & 20 & $t^{\mathrm{a}}$ & + & + & - \\
\hline Nonflooded (indoor experiment, 2013) & 20 & + & + & + & - \\
\hline Nonflooded (field experiment, 2013) & 20 & + & + & + & - \\
\hline Nonflooded (field experiment, 2014) & 20 & + & + & + & - \\
\hline Flooded (field experiment, 2013) & 16 & + & + & + & - \\
\hline Flooded (field experiment, 2014) & 3 & + & + & + & - \\
\hline \multicolumn{6}{|l|}{ B. napus } \\
\hline Rothamsted, UK, 1996 & 1 (UK-1, L. maculans) & nd & nd & - & + \\
\hline Hubei, China, 2010 & 1 (W10, L. biglobosa) & + & + & + & - \\
\hline
\end{tabular}

a Symbols + and - indicate the presence or absence, respectively, of a trait or DNA marker; nd = not determined, because the axenic cultures of isolate UK-1 of L. maculans are not available. The genomic DNA of isolate UK-1 was kindly provided by Drs. Y. J. Huang and B. D. L. Fitt of the University of Hertfordshire (Hatfield, Hertfordshire, UK).

${ }^{b}$ Multiplex polymerase chain reaction (PCR) with the specific primers LbigF, LmacF, and LmacR reported by Liu et al. (2006).

${ }^{\mathrm{c}}$ Isolates were incubated on V8-juice agar at $25^{\circ} \mathrm{C}$ for 10 days for observation of brown pigments, pycnidia, and pycnidiospores (conidia). 
ribosomal DNA, actin, and $\beta$-tubulin sequences. In the present study, all 99 isolates of L. biglobosa from the diseased stubble of winter oilseed rape produced a 444-bp DNA fragment in multiplex PCR (Fig. 4; Table 1). Presence of the DNA marker in these isolates suggests that they belong to L. biglobosa 'brassicae' (Liu et al. 2006). In Canada, L. maculans 'brassicae' and L. biglobosa 'canadensis' coexist on spring oilseed rape (Mendes-Pereira et al. 2003; Vincenot et al. 2008) and flooding reduced survival of both pathogens (Peluola et al. 2013). Because survival of L. biglobosa 'brassicae' (Figs. 1, 2, and 3), L. biglobosa 'canadensis', and L. maculans 'brassicae' (Peluola et al. 2013) is reduced by flooding, the implications are that all three pathogens are quite similar in sensitivity to flooding.

In central China, in addition to oilseed rape-rice rotation, other rotation practices such as oilseed rape-cotton rotation and oilseed rape-maize rotation are also used in the production of oilseed rape (Hu and Ding 2008). Moreover, these diversified cultivation models coexist in many oilseed rape-growing areas. The present study indicated that viable L. biglobosa 'brassicae' can be recovered from winter oilseed rape stubble placed on the soil surface in a cotton field (Figs. 2 and 3), thus suggesting that the pathogen is able to survive fluctuating dry and wet conditions that occur during the summer in central China. Viable L. biglobosa 'brassicae' produces pseudothecia and ascospores during conducive temperature and moisture conditions in autumn to winter, and in early spring. The ascospores are dispersed to oilseed rape plants in different fields, where they initiate a new round of infection (Fitt et al. 2006a; Li et al. 2013). Survival of L. biglobosa 'brassicae' in oilseed rape residues in dryland fields is probably the reason for the frequent occurrence of blackleg on oilseed rape in central China, in spite of adoption of oilseed rape-cotton (or-maize or-soybean) rotation in this area.

Thus far, L. maculans has not been found in China (Cai et al. 2011, 2014 a,b; Hao et al. 2014; Li et al. 2013); however, epidemiological risk of $L$. maculans on oilseed rape in China still exists due to the diversified oilseed rape cultivation models and lack of resistant cultivars in this country (Fitt et al. 2008). Strict quarantine of the imported seed of oilseed rape and cruciferous vegetables is still needed to prevent $L$. maculans from entering China.

The present study showed that flooded stem pieces of oilseed rape decomposed rapidly (Figs. 1, 2, and 3) and confirmed results reported in a previous study by Peluola et al. (2013). Decomposition of the stem pieces of oilseed rape is positively correlated with reduced retrieval of viable L. biglobosa 'brassicae' from the stem pieces. Microorganisms living on the oilseed rape stubble are likely responsible for decomposition of the stem pieces and for reducing survival of L. biglobosa 'brassicae' in the stubble. Blenis and Chow (2005) proposed using fungi to decompose oilseed rape stubble, to thereby reduce the survival of L. maculans and L. biglobosa. Naseri et al. (2008) reported that a few saprophytic fungi such as Trichoderma spp. could colonize stubble of oilseed rape, thus producing adverse effects on survival of L. maculans, possibly through mycoparasitism, competition, predation, or antibiosis. Future studies to characterize microorganisms associated with oilseed rape stubble in flooded and dryland fields are necessary in order to identify microbial species that suppress the survival of L. biglobosa 'brassicae' in infested stubble.

\section{Acknowledgments}

This research was funded by the National Science and Technology Supporting Program (grant number 2010BAD01B04) and China Agriculture Research System (grant CARS-13)

\section{Literature Cited}

Balesdent, M. H., Barbetti, M. J., Li, H., Sivasithamparam, K., Gout, L., and Rouxel, T. 2005. Analysis of Leptosphaeria maculans race structure in a worldwide collection of isolates. Phytopathology 95:1061-1071.

Barnes, A. P., Wreford, A., Butterworth, M. H., Semonov, M. A., Moran, D., Evans, N., and Fitt, B. D. L. 2010. Adaptation to increasing severity of Phoma stem canker on winter oilseed rape in the UK under climate change. J. Agric. Sci. 148:683-694.

Blenis, P. V., and Chow, P. S. 2005. Evaluating fungi from wood and canola for their ability to decompose canola stubble. Can. J. Plant Pathol. 27:259-267.

Cai, X., Wang, Z. H., Li, G. Q., Jiang, D. H., and Huang, J. B. 2011. Pathogen identification and field survey of blackleg disease on oilseed rape in Hubei
Province of China. Page 71 in: Proc. Annu. Meet. Chin. Soc. Plant Pathol Z. J. Guo and M. S. Hou, eds. China Agriculture Scientech Press, Beijing.

Cai, X., Yang, L., Zhang, J., and Li, G. Q. 2014a. First report of Leptosphaeria biglobosa causing black leg on Brassica campestris ssp. chinensis var. purpurea in central China. Plant Dis. 98:1156.

Cai, X., Yang, L., Zhang, J., and Li, G. Q. 2014b. First report of Leptosphaeria biglobosa causing black leg on Raphanus sativus in central China. Plant Dis. 98:993.

Chen, G. Y., Wu, C. P., Li, B., Su, H., Zhen, S. Z., and An, Y. L. 2010. Detection of Leptosphaeria maculans from imported oilseed rape seeds. J. Plant Dis. Prot. 117:173-176.

Dilmaghani, A., Balesdent, M. H., Rouxel, T., and Moreno-Rico, O. 2010. First report of Leptosphaeria biglobosa (blackleg) on Brassica oleracea (cabbage) in Mexico. Plant Dis. 94:791.

Fitt, B. D. L., Brun, H., Barbetti, M. J., and Rimmer, S. R. 2006a. World-wide importance of Phoma stem canker (Leptosphaeria maculans and L. biglobosa) on oilseed rape (Brassica napus). Eur. J. Plant Pathol. 114:3-15.

Fitt, B. D. L., Hu, B. C., Li, Z. Q., Liu, S. Y., Lange, R. M., Kharbanda, P. D., Butterworth, M. H., and White, R. P. 2008. Strategies to prevent spread of Leptosphaeria maculans (Phoma stem canker) onto oilseed rape crops in China; costs and benefits. Plant Pathol. 57:652-664.

Fitt, B. D. L., Huang, Y. J., van den Bosch, F., and West, J. S. 2006b. Coexistence of related pathogen species on arable crops in space and time. Annu. Rev. Phytopathol. 44:163-182.

Ghanbarnia, K., Fernando, W. G. D., and Crow, G. 2011. Comparison of disease severity and incidence at different growth stages of naturally infected oilseed rape plants under field conditions by pycnidiospores of Phoma lingam as a main source of inoculum. Can. J. Plant Pathol. 33:355-363.

Hall, R. 1992. Epidemiology of blackleg of oilseed rape. Can. J. Plant Pathol. 14:46-55

Hall, R., Chigogora, J. L., and Phillips, L. G. 1996. Role of seedborne inoculum of Leptosphaeria maculans in development of blackleg on oilseed rape. Can. J. Plant Pathol. 18:35-42.

Hammond, K., Lewis, B., and Musa, T. 1985. A systemic pathway in the infection of oilseed rape plants by Leptosphaeria maculans. Plant Pathol. 34:557-565.

Hao, L. F., Song, P. L., Li, Z. Q., Huangpu, H. Y., and Li, Q. S. 2014. Genetic diversity of Phoma stem canker pathogen Leptosphaeria biglobosa by ISSR. Chin. J. Oil Crop Sci. 36:98-105.

Hu, L. Y., and Ding, J. F. 2008. Crop Cultivation. China Higher Education Press, Beijing.

Huang, Y. J., Liu, Z., West, J. S., Todd, A. D., Hall, A. M., and Fitt, B. D. L. 2007. Effects of temperature and rainfall on date of release of ascospores of Leptosphaeria maculans (Phoma stem canker) from winter oilseed rape (Brassica napus) debris in the UK. Ann. Appl. Biol. 151:99-111.

Li, H., Tapper, N., Dean, N., Barbetti, M., and Sivasithamparam, K. 2006. Enhanced pathogenicity of Leptosphaeria maculans pycnidiospores from paired co-inoculation of Brassica napus cotyledons with ascospores. Ann. Bot. (Lond.) 97:1151-1156.

Li, Q. S., Rong, S. B., Hu, B. C., Jiang, Y. F., Hou, S. M., Fei, W. X., Chen, F. X., Wu, X. J., Fan, Z. X., and Lei, W. X. 2013. Distribution of blackleg disease on oilseed rape in China and its pathogen identification. Chin. J. Oil Crop Sci. 35: 415-423.

Liu, S. Y., Liu, Z., Fitt, B. D. L., Evans, N., Foster, S. J., Huang, Y. J., LatundeDada, A. O., and Lucas, J. A. 2006. Resistance to Leptosphaeria maculans (Phoma stem canker) in Brassica napus (oilseed rape) induced by Leptosphaeria biglobosa and chemical defence activators in field and controlled environments. Plant Pathol. 55:401-412.

Marcroft, S. J., Sprague, S. J., Pymer, S. J., Salisbury, P. A., and Howlett, B. J. 2004. Crop isolation, not extended rotation length, reduces blackleg (Leptosphaeria maculans) severity of oilseed rape (Brassica napus) in southeastern Australia. Aust. J. Exp. Agric. 44:601-606.

Mendes-Pereira, E., Balesdent, M. H., Brun, H., and Rouxel, T. 2003. Molecular phylogeny of the Leptosphaeria maculans - L. biglobosa species complex. Mycol. Res. 107:1287-1304.

Möller, E. M., Bahnweg, G., Sandermann, H., and Geige, H. H. 1992. A simple and efficient protocol for isolation of high molecular weight DNA from filamentous fungi, fruit bodies, and infected plant tissues. Nucleic Acids Res. 20:6115-6116.

Moore, W. 1949. Flooding as a means of destroying the sclerotia of Sclerotinia sclerotiorum. Phytopathology 39:920-927.

Naseri, B., Davidson, J. A., and Scott, E. S. 2008. Survival of Leptosphaeria maculans and associated mycobiota on oilseed rape stubble buried in soil. Plant Pathol. 57:280-289.

Peluola, C., Fernando, W. G. D., Huvenaars, C., Kutcher, H. R., Lahlali, R., and Peng, G. 2013. Effect of flooding on the survival of Leptosphaeria spp. in oilseed rape stubble. Plant Pathol. 62:1350-1356.

Sosnowski, M. R., Scott, E. S., and Ramsey, M. D. 2006. Survival of Leptosphaeria maculans in soil on residues of Brassica napus in South Australia. Plant Pathol. 55:200-206.

Sprague, S. J., Watt, M., Kirkegaard, J. A., and Howlett, B. J. 2007. Pathways of infection of Brassica napus roots by Leptosphaeria maculans. New Phytol. 176:211-222.

Travadon, R., Bousset, L., Saint-Jean, S., Brun, H., and Sache, I. 2007. Splash dispersal of Leptosphaeria maculans pycnidiospores and the spread of blackleg on oilseed rape. Plant Pathol. 56:595-603. 
Vincenot, L., Balesdent, M. H., Li, H., Barbetti, M. J., Sivasithamparam, K., Gout, L., and Rouxel, T. 2008. Occurrence of a new subclade of Leptosphaeria biglobosa in Western Australia. Phytopathology 98:321-329.

West, J. S., Evans, N., Liu, S., Hu, B., and Peng, L. 2000. Leptosphaeria maculans causing stem canker of oilseed rape in China. Plant Pathol. 49:800.

West, J. S., Kharbanda, P. D., Barbetti, M. J., and Fitt, B. D. L. 2001. Epidemiology and management of Leptosphaeria maculans (Phoma stem canker) on oilseed rape in Australia, Canada and Europe. Plant Pathol. 50: $10-27$.
World Meteorological Organization. 2014. Climatological information-Wuhan, China. Online publication. http://www.worldweather.org/001/c00351.htm

Yang, L., Li, G. Q., Long, Y. Q., Hong, G. P., Jiang, D. H., and Huang, H. C. 2010

Effects of soil temperature and moisture on survival of Coniothyrium minitans conidia in central China. Biol. Control 55:27-33.

Zhang, X., White, R. P., Demir, E., Jedryczka, M., Lange, R. M., Islam, M., Li, Z. Q., Huang, Y. J., Hall, A. M., Zhou, G., Wang, Z., Cai, X., Skelsey, P., and Fitt, B. D. L. 2014. Leptosphaeria spp., Phoma stem canker and potential spread of L. maculans on oilseed rape crops in China. Plant Pathol. 63:598-612. 